\title{
Low temperature induced alterations in certain biochemical constituents of 5 th instar larvae of Philosamia ricini (Lepidoptera: Satunidae)
}

This article was published in the following Dove Press journal:

Open Access Insect Physiology

3 July 2010

Number of times this article has been viewed

\author{
Anita Singh \\ Ratnesh Kr Sharma \\ Bechan Sharma \\ Department of Biochemistry, \\ University of Allahabad, Allahabad, \\ UP, India
}

Correspondence: Bechan Sharma Department of Biochemistry, University of Allahabad, Allahabad-21 I002, UP, India

Tel +9l 94I 57| 5639

Fax +9| 532246 II57

Email bechansharma@gmail.com

\begin{abstract}
Studies on cold acclimation of insects including silkworms have shown significant variations in the levels of various biomolecules to cope with heat-shock. The present study has been carried out on cold-stressed 5th instar Philosamia ricini Hutt larvae to assess the physiological strategy adopted by this silkworm species for its survival at low temperatures. In this study, various biochemical assays have been performed in hemolymph, silk gland, and fat body of the larvae. The results revealed that exposure to low temperatures $\left(10^{\circ} \mathrm{C} \pm 1{ }^{\circ} \mathrm{C}\right)$ leads to the accumulation of high levels of glycerol content in hemolymph, silk gland, and fat body of larvae in comparison with control group reared at ambient temperature conditions $\left(25^{\circ} \mathrm{C} \pm 3^{\circ} \mathrm{C}\right)$. The treatment of $P$. ricini larvae with low temperatures resulted in decreased trehalose content in all 3 insect tissues tested. The activities of phosphatases (acid and alkaline) were found to be significantly increased. However, the activities of aminotransferases (L-alanine-2-oxoglutarate aminotransferase [GPT, EC: 2.6.1.2] and L-aspartate-2-oxoglutarate aminotransferase [GOT, EC: 2.6.1.1]) were significantly inhibited in the hemolymph. The data indicated that trehalose could function as the major carbohydrate source of energy in acclimated 5th instar P. ricini larvae, whereas glycerol appears to confer cryoprotection.
\end{abstract}

Keywords: acclimation, aminotransferases, hydrolases, silk gland, hemolymph

\section{Introduction}

Insects have evolved different physiological strategies to overcome drastic and adverse changes in their surrounding environment. Temperature plays a major role in their physiological behavior. The profound acclimative changes to low temperature in the metabolism of insects, especially lepidopterans by production of various cryoprotectants like glycerol, trehalose, sorbitol etc are well known. ${ }^{1-6}$ Several species of freeze-tolerant insects are reported to accumulate glycerol or other polyols during autumn and winter. ${ }^{7}$ The importance of glycerol accumulation in winter survival of various dipausing insects has also been reported in a number of studies. ${ }^{2,8,9}$

Although the adaptive strategies exhibited by various insects in response to temperature variations are well known, only a few studies show the change in rate of acclimation in insects in response to extreme temperatures such as cold stress. For the present study, we have selected Philosamia ricini Hutt, which is a continuously breeding lepidopteran and does not go into diapause. P. ricini silkworm has been used due to its capability of smooth rearing and survival at the ambient environmental conditions in the Allahabad region. The major developments in larvae take place between the 3rd and 5th instar stages, and at the culmination of the 5th instar stage they spin a silk cocoon and change into pupae. ${ }^{10}$ The pupae spend 3 weeks in the cocoon and then 
emerge as imago to mate and lay eggs. The eggs hatch into worms in a few weeks, and their life cycle continues.

However, there are very few reports available regarding impact of low temperatures on the metabolic or physiological activities of the silk worms. Keeping these facts in view, we subjected 5th instar larvae of $P$. ricini to cold stress in order to find out the variations in the levels of various biomolecules such as proteins, total carbohydrates, trehalose, total free amino acids and glycerol, which play crucial roles in regulating various physiological activities of the insect. In addition, the activities of some key enzymes such as alkaline and acid phosphatases [EC: 3.1.3.1 and 2; AcP and AlP] as well as L-alanine-2-oxoglutarate aminotransferase [GPT, EC: 2.6.1.2] and L-aspartate-2-oxoglutarate aminotransferase [GOT, EC: 2.6.1.1] have also been determined. The activity of AcP has been implicated in pupal development and reproduction of the insect, ${ }^{11}$ whereas the activities of GPT and GOT are involved in protein metabolism in major tissues like silk gland, fat body and hemolymph. ${ }^{12}$ The study would help in understanding the physiological strategy adopted by silkworm species to withstand low temperatures.

\section{Materials and methods}

Newly hatched larvae of $P$. ricini (200) were reared on tender fresh leaves of castor plants (Ricinus communis) in the laboratory at $25^{\circ} \mathrm{C} \pm 3^{\circ} \mathrm{C}$ and humidity $90 \%-95 \%$. The 5 th instar larvae of the insect were divided into 4 groups; each containing an equal number (50) of larvae in plastic trays. One of the groups served as a control (reared at $25^{\circ} \mathrm{C} \pm 3{ }^{\circ} \mathrm{C}$ ) and the other 3 were acclimated at $10^{\circ} \mathrm{C} \pm 1{ }^{\circ} \mathrm{C}$ for varying treatment durations $(2,4$, and 7 days). Their weights, mortality rate, and morphological change were recorded on alternate days up to 7 days of treatment duration.

After 7 days of exposure, their hemolymph was collected. The larvae were dissected in ice-cold Bodenstein's Ringer solution, and their silk glands and fat body were excised out. $^{13,14}$ The $20 \%$ (w/v) homogenates of silk gland and fat body were prepared in $50 \mathrm{mM}$ Tris- $\mathrm{HCl}$ buffer $(\mathrm{pH} 7.0)$ in a Potter Elvenhauz homogenizer. The homogenate was centrifuged at $10,000 \mathrm{rpm}$ and $4^{\circ} \mathrm{C}$ for 30 minutes. Supernatant was collected for quantitative estimation of the metabolites.

Total protein content was assayed as described earlier by Lowry et al, ${ }^{15}$ whereas total carbohydrate was determined according to Trevelyan and Harrison. ${ }^{16}$ Trehaolse was estimated by the method described by Wyatt and Kalf, ${ }^{17}$ and total free amino acids were assayed by the method of Rosen. ${ }^{18}$ Glycerol content was estimated by the method described by Korn. ${ }^{19}$ The activities of enzymes acid and alkaline phosphatases were assayed by the method described by Fiske and Subbarow. ${ }^{20}$ Glutamic-pyruvic transaminase (GPT) and glutamic-oxaloacetic transaminase (GOT) were estimated by the method described by Reitman and Frankel. ${ }^{21}$

\section{Statistical analysis}

Each assay was replicated 3-4 times. Values were expressed as mean \pm SE of replication and Student's $t$-test was applied to locate significant $(P<0.05)$ differences between treated and control groups.

\section{Results}

The rates of survival and mortality were determined by incubating the insect larvae at a low temperature $\left(10^{\circ} \mathrm{C} \pm 1^{\circ} \mathrm{C}\right)$ for varying treatment periods and comparing the count of living organisms with those incubated at room temperature $\left(25^{\circ} \mathrm{C} \pm 3^{\circ} \mathrm{C}\right)$ as shown in the Materials and methods section. Low-temperature exposure of the larvae of $P$. ricini for 7 days resulted in a high rate of mortality to the extent of $30 \%$ ( $P \leq 0.05)$. When the larvae were reverted back to normal temperatures, all remaining insects became flaccid and lost the capacity to spin normal cocoons. Fifty percent of the larvae died on the 8 th day. At the end of the 11 th day all larvae were found dead. Marked loss in body weight of the larvae due to cold treatment was also observed. Larvae lost about $20 \%$ of their body weight on the 7 th day of incubation at low temperature (data not shown).

The impact of low temperature treatment on the 5th instar larvae of $P$. ricini was also observed. After 7 days exposure to $10^{\circ} \mathrm{C}$, the skin color of larvae changed to yellowish green from its initial greenish white color. The body size of the larvae was observed to be reduced. The larvae became sluggish and flaccid in appearance. When the larvae subjected to 7 days cold stress were kept at room temperature for 3-4 days, approximately 40\% loss in body weight was recorded. The color of the larvae changed to black leading to $100 \%$ lethality (data not shown).

The exposure of the insect larvae to low temperature is expected to lead some changes in its biochemical constituents. Hence, the experiments were conducted to estimate the levels of some key biomolecules such as proteins, total carbohydrates including trehalose, total free amino acids, and glycerol using standard procedures as described in the Materials and methods section. The results shown in Tables 1-3 indicate that cold stress profoundly affects the levels of proteins, carbohydrates, trehalose, free amino acids and glycerol contents in different parts of the insect larvae. 
Table I Effect of exposure to low temperature on some biomolecules in the hemolymph of the 5th instar larvae of Philosamia ricini for 2, 4, and 7 days

\begin{tabular}{|c|c|c|c|c|}
\hline \multirow[t]{2}{*}{ Parameters } & \multirow{2}{*}{$\begin{array}{l}\text { Control } \\
(\mathrm{mg} / \mathrm{ml})\end{array}$} & \multicolumn{3}{|c|}{ Experimental $(\mathrm{mg} / \mathrm{ml})$} \\
\hline & & 2 days & 4 days & 7 days \\
\hline Protein & $15.1 \pm 0.29$ & $\begin{array}{l}|7.2 \pm 0.3| \\
(+\mid 3.9)\end{array}$ & $\begin{array}{l}20.4 \pm 0.18 \\
(+35.1)\end{array}$ & $\begin{array}{l}25.5 \pm 0.77 \\
(+68.9)\end{array}$ \\
\hline Carbohydrate & $\mid 1.6 \pm 0.31$ & $\begin{array}{l}10.1 \pm 0.24^{a} \\
(12.9)\end{array}$ & $\begin{array}{l}9.5 \pm 0.19 \\
(18.1)\end{array}$ & $\begin{array}{l}8.1 \pm 0.18 \\
(30.2)\end{array}$ \\
\hline Trehalose & $10.0 \pm 0.04$ & $\begin{array}{l}8.0 \pm 0.18 \\
(20.0)\end{array}$ & $\begin{array}{l}7.2 \pm 0.23^{\mathrm{a}} \\
(28.0)\end{array}$ & $\begin{array}{l}5.7 \pm 0.18 \\
(43.0)\end{array}$ \\
\hline $\begin{array}{l}\text { Free amino } \\
\text { acid }\end{array}$ & $9.1 \pm 0.24$ & $\begin{array}{l}10.1 \pm 0.23 \\
(+10.9)\end{array}$ & $\begin{array}{l}I I .0 \pm 0.7 \\
(20.8)\end{array}$ & $\begin{array}{l}11.7 \pm 0.29 \\
(+28.6)\end{array}$ \\
\hline Glycerol & $5.5 \pm 0.18$ & $\begin{array}{l}6.5 \pm 0.17 \\
(+18.2)\end{array}$ & $\begin{array}{l}7.7 \pm 0.29 \\
(+40.0)\end{array}$ & $\begin{array}{l}10.4 \pm 0.23^{2} \\
(+89.1)\end{array}$ \\
\hline
\end{tabular}

Notes: The $P$. ricini 5 th instar larvae (50 in each experimental set) were acclimated up to 7 days at $10^{\circ} \mathrm{C} \pm 1{ }^{\circ} \mathrm{C}$ for the experimental set, whereas the control group insects were reared at $25^{\circ} \mathrm{C} \pm 3^{\circ} \mathrm{C}$ for the similar period. The biomolecules were estimated using the standard procedures as described in the Materials and methods section. Each value represents the mean \pm SEM of 3 different observations. The values presented in parentheses indicate the percentage increase $(+)$ or decrease $(-)$ over control. ${ }^{a}$ Significantly different at $P \leq 0.05$ (Students' $t$-test).

When compared with the control, the levels of protein $(14 \%-69 \%)$, total free amino acids $(11 \%-29 \%)$, and glycerol $(18 \%-89 \%)$ were found to be increased in the hemolymph of cold-stressed larvae after the treatment durations from 1 day to 7 days (Table 1). The results also reflected that the cold-stress treatment of 7 days caused drastic change in the levels of protein and glycerol to the maximum extent; the rise in the values being $69 \%$ and $89 \%$, respectively. The level of

Table 2 Effect of exposure to low temperature on some biomolecules in the silk gland of 5 th instar larvae of Philosamia ricini for 2, 4, and 7 days

\begin{tabular}{lllll}
\hline Parameters & $\begin{array}{l}\text { Control } \\
\text { (mg/g wet } \\
\text { wt. tissue) }\end{array}$ & \multicolumn{3}{l}{ Experimental (mg/g wet wt. tissue) } \\
\cline { 3 - 5 } & $108.0 \pm 0.7$ & $95.5 \pm 0.34$ & $\mathbf{4}$ days & $\mathbf{7}$ days \\
\hline Protein & & $(11.5)$ & $(20.2)$ & $(31.5)$ \\
Carbohydrate & $49.5 \pm 0.18$ & $56.2 \pm 0.31$ & $61.4 \pm 0.33$ & $71.5 \pm 0.22^{\mathrm{a}}$ \\
& & $(+13.5)$ & $(+24.0)$ & $(+54.4)$ \\
Trehalose & $43.5 \pm 0.24$ & $41.2 \pm 0.28$ & $39.6 \pm 0.30$ & $37.0 \pm 0.32^{\mathrm{a}}$ \\
& & $(5.3)$ & $(8.9)$ & $(14.9)$ \\
Free amino & $16.5 \pm 0.18$ & $21.2 \pm 0.15^{\mathrm{a}}$ & $28.5 \pm 0.14$ & $36.0 \pm 0.12$ \\
acid & & $(+28.5)$ & $(+72.7)$ & $(+118.2)$ \\
Glycerol & $20.5 \pm 0.18$ & $26.0 \pm 0.12$ & $32.0 \pm 0.30^{\mathrm{a}}$ & $43.5 \pm 0.24^{\mathrm{a}}$ \\
& & $(+26.8)$ & $(+56.1)$ & $(+112.2)$ \\
\hline
\end{tabular}

Notes: The $P$. ricini 5 th instar larvae (50 in each experimental set) were acclimated up to 7 days at $10^{\circ} \mathrm{C} \pm 1{ }^{\circ} \mathrm{C}$ for the experimental set, whereas the control group insects were reared at $25^{\circ} \mathrm{C} \pm 3^{\circ} \mathrm{C}$ for the similar period. The biomolecules were estimated using the standard procedures as described in the Materials and methods section. Each value represents the mean \pm SEM of 3 different observations. The values presented in parentheses indicate the percentage increase $(+)$ or decrease $(-)$ over control. a'Significantly different at $P \leq 0.05$ (Students' $t$-test).
Table 3 Effect of exposure to low temperature on some biomolecules in the fat body of the 5 th instar larvae of Philosamia ricini for 2, 4, and 7 days

\begin{tabular}{lllll}
\hline Parameters & $\begin{array}{l}\text { Control } \\
\text { (mg/g wet }\end{array}$ & \multicolumn{3}{l}{ Experimental ( $\mathbf{m g} / \mathbf{g}$ wet wt. tissue) } \\
\cline { 3 - 5 } & wt. tissue) & & $\mathbf{4}$ days & $\mathbf{7}$ days \\
\hline Protein & $92.0 \pm 0.31$ & $82.6 \pm 0.16$ & $74.5 \pm 0.17^{\mathrm{a}}$ & $64.5 \pm 0.19$ \\
& & $(10.2)$ & $(19.0)$ & $(29.9)$ \\
Carbohydrate & $51.5 \pm 0.24$ & $49.7 \pm 0.12$ & $48.5 \pm 0.15^{\mathrm{a}}$ & $47.0 \pm 0.10^{\mathrm{a}}$ \\
& & $(3.5)$ & $(5.8)$ & $(8.7)$ \\
Trehalose & $45.5 \pm 0.24$ & $42.5 \pm 0.20$ & $38.2 \pm 0.22^{\mathrm{a}}$ & $34.5 \pm 0.18$ \\
& & $(6.6)$ & $(16.0)$ & $(24.2)$ \\
Free amino & $22.0 \pm 0.23$ & $21.2 \pm 0.22$ & $19.0 \pm 0.2 \mathrm{I}^{\mathrm{a}}$ & $17.5 \pm 0.24$ \\
acid & & $(3.6)$ & $(13.6)$ & $(20.5)$ \\
Glycerol & $12.5 \pm 0.18$ & $14.0 \pm 0.1 \mathrm{I}^{\mathrm{a}}$ & $18.5 \pm 0.18$ & $22.5 \pm 0.18^{\mathrm{a}}$ \\
& & $(+12.0)$ & $(+48.0)$ & $(+80.0)$ \\
\hline
\end{tabular}

Notes: $P$. ricini 5 th instar larvae (50 in each experimental set) was acclimated for 7 days at $10^{\circ} \mathrm{C} \pm 1{ }^{\circ} \mathrm{C}$ for the experimental set, whereas the control group insects were reared at $25^{\circ} \mathrm{C} \pm 3^{\circ} \mathrm{C}$. The biomolecules were estimated using the standard procedures as described in the Materials and methods section. Each value represents the mean \pm SEM of 3 different observations. The values presented into the parentheses indicate the percent increase $(+)$ or decrease $(-)$ over control. aSignificantly different at $P \leq 0.05$ (Students' $t$-test).

another key biomolecule, free amino acids, was found to be increased by $29 \%$ only under same treatment conditions. In contrast, the significant $(P \leq 0.05)$ decrease in the levels of total carbohydrate (up to $30 \%$ ) and trehalose (up to $43 \%$ ) was recorded in the hemolymph of cold-stressed subjects (Table 1). The data suggest that the impact of the cold stress on the insect larvae was dependent on the duration of treatment.

Similar experiments were conducted in the silk gland of the insect. The results as presented in Table 2 indicate marked increase in total carbohydrate by about $13 \%-54 \%$. However, the levels of protein and trehalose deceased, respectively, by $12 \%-32 \%(P \leq 0.05)$ and $5 \%-15 \%$. A significantly high increase in the concentration in the total free amino acids and glycerol content ranged up to $29 \%-118 \%$ and $27 \%-112 \%$, respectively, after 7 days cold exposure to the 5 th instar larvae. The results also reflected that the cold-stress treatment of 7 days caused drastic changes in the levels of free amino acid and glycerol to the maximum extent; the values being $118 \%$ and $112 \%$, respectively (Table 2). Also, the biochemical analyses carried out on fat body of cold-stressed 5 th instar larvae showed a remarkable increase in the level of glycerol in the range of $12 \%-80 \%$ as compared with the control group (Table 3). However, only a small decrease was observed in the levels of protein, carbohydrate, trehalose, and total free amino acids (Table 3); the values being in the range of $10 \%-30 \%$, $6 \%-9 \%, 4 \%-21 \%$, and $7 \%-24 \%(P \leq 0.05)$ for protein, total carbohydrate, free amino acids, and trehalose, respectively. 
Apart from studying the levels of some key biomolecules in cold-stressed 5th instar larvae of $P$. ricini, the effects of low temperature on the activities of some important enzymes were observed. The results presented in Table 4 indicate that the activities of these enzymes reflect the impact of cold stress differently. The activities of one of the hydrolases, alkaline phosphatase, showed a very significant increase in the range of $22 \%-67 \%(P \leq 0.05)$ in the hemolymph of the insect larvae. In contrast, the level of acid phosphatase registered a significant $(P \leq 0.05)$ decrease in the range of $12 \%-28 \%$ due to cold stress. The activities of the aminotransferases such as GPT and GOT also decreased in the range of $17 \%-54 \%$ and $28 \%-63 \%$, respectively, when compared with the control group larvae (Table 4). The impact of cold stress on the activities of these enzymes from hemolymph was found to be dependent on duration of cold treatment.

The similar study was conducted to assess the impact of cold stress on the activities of these enzymes isolated from the silk gland of 5 th instar larvae of $P$. ricini. The results presented in Table 5 showed that the cold-stress treatment resulted in a very drastic increase in the activity of hydrolases (acid and alkaline phospahatases) as well as transaminases (GPT and GOT); the values of percentage increase being $123 \%, 299 \%, 210 \%$ and $119 \%$, respectively, after the 7 th day of treatment. The extents of increase in acid and alkaline phosphatases were found to be $33 \%-123 \%$ and $75 \%-299 \%$

Table 4 Effect of exposure to low temperature $\left(10^{\circ} \mathrm{C}\right)$ on some key enzymes in the hemolymph of 5 th instar larvae of Philosamia ricini for 2, 4, and 7 days

\begin{tabular}{lllll}
\hline Enzymes & $\begin{array}{l}\text { Control } \\
\text { (units } \mathbf{~ m g}^{-1}\end{array}$ & \multicolumn{3}{l}{ Experimental (units $\mathbf{~ m g}^{-1}$ protein) } \\
\cline { 3 - 5 } & protein) & days & 4 days & 7 days \\
\hline Acid & $56.9 \pm 0.16$ & $50.0 \pm 0.20^{c}$ & $45.2 \pm 0.14$ & $41.2 \pm 0.49$ \\
phosphatase $^{\mathrm{a}}$ & & $(12.1)$ & $(20.5)$ & $(27.7)$ \\
Alkaline & $15.2 \pm 0.04$ & $18.5 \pm 0.14$ & $22.5 \pm 0.28^{\mathrm{c}}$ & $25.5 \pm 0.15$ \\
phosphatase & & $(+21.7)$ & $(+48.0)$ & $(+67.4)$ \\
GPT & $24.4 \pm 1.32$ & $20.2 \pm 0.72$ & $16.5 \pm 0.75^{\mathrm{c}}$ & $11.2 \pm 0.8 \mathrm{I}^{\mathrm{c}}$ \\
& & $(17.2)$ & $(32.4)$ & $(54.3)$ \\
GOT & $96.5 \pm 1.22$ & $70.0 \pm 1.40$ & $48.6 \pm 1.45$ & $35.7 \pm 1.53^{\mathrm{c}}$ \\
& & $(27.5)$ & $(49.6)$ & $(62.9)$ \\
\hline
\end{tabular}

Notes: $P$. ricini 5 th instar larvae (50 in each experimental set) was acclimated for 7 days at $10^{\circ} \mathrm{C} \pm 1{ }^{\circ} \mathrm{C}$ for the experimental set, whereas the control group insects were reared at $25^{\circ} \mathrm{C} \pm 3^{\circ} \mathrm{C}$. I unit of phosphatase has been defined as the I mg Pi per $100 \mathrm{~mL} / \mathrm{h}$ and I unit of the activity of transaminases as I mM pyruvate per $\mathrm{mL}$ per 30 minutes for GPT and per 60 minutes for GOT. The specific activity has been expressed as units/mg protein. The results represent the average values of 3 independent experiments. The values in parentheses indicate percent increase $(+)$ or decrease (-) over control. a,bThe values are to be multiplied by a factor of $10 .^{4}$ 'Significantly different at $P \leq 0.05$ (Students' $t$-test).

Abbreviations: GPT, glutamic-pyruvic transaminase; GOT, glutamic-oxaloacetic transaminase.
Table 5 Effect of exposure to low temperature $\left(10^{\circ} \mathrm{C}\right)$ on some key enzymes in the silk gland of 5 th instar larvae of Philosamia ricini for 2, 4, and 7 days

\begin{tabular}{lllll}
\hline Enzymes & $\begin{array}{l}\text { Control } \\
\text { (units } \mathbf{~ m g}^{-1} \\
\text { protein }\end{array}$ & \multicolumn{3}{l}{ Experimental (units $\mathbf{~ m g}^{-1}$ protein) } \\
\cline { 3 - 5 } & 2 days & $\mathbf{4}$ days & $\mathbf{7}$ days \\
\hline Acid & $22.2 \pm 0.20$ & $30.2 \pm 0.16$ & $39.4 \pm 0.15^{c}$ & $50.7 \pm 0.14^{c}$ \\
phosphatase $^{\mathrm{a}}$ & & $(+33.0)$ & $(+73.5)$ & $(+123.4)$ \\
Alkaline & $8.8 \pm 0.70$ & $15.4 \pm 0.17^{\mathrm{c}}$ & $24.8 \pm 0.15$ & $35.1 \pm 0.14$ \\
phosphatase & & $(+75.0)$ & $(+181.8)$ & $(+299.3)$ \\
GPT & $31.7 \pm 1.84$ & $52.2 \pm 0.78$ & $65.4 \pm 0.74$ & $98.5 \pm 0.8$ \\
& & $(+64.6)$ & $(+106.3)$ & $(+210.6)$ \\
GOT & $28.5 \pm 2.14$ & $\begin{array}{l}36.6 \pm 1.50^{c} \\
(+28.4)\end{array}$ & $48.2 \pm 1.48$ & $62.5 \pm 1.53^{c}$ \\
& & $(+69.1)$ & $(+119.1)$ \\
\hline
\end{tabular}

Notes: $P$. ricini 5 th instar larvae (50 in each experimental set) was acclimated for 7 days at $10^{\circ} \mathrm{C} \pm 1{ }^{\circ} \mathrm{C}$ for the experimental set, whereas the control group insects were reared at $25^{\circ} \mathrm{C} \pm 3^{\circ} \mathrm{C}$. I unit of phosphatase has been defined as the I mg Pi per $100 \mathrm{~mL} / \mathrm{h}$ and I unit of the activity of transaminases as I mM pyruvate per $\mathrm{mL}$ per 30 minutes for GPT and per 60 minutes for GOT. The specific activity has been expressed as units/mg protein. The results represent the average values of 3 independent experiments. The values in parentheses indicate percent increase $(+)$ or decrease (-) over control. a,bThe values are to be multiplied by a factor of $10 .{ }^{4}$ 'Significantly different at $P \leq 0.05$ (Students' $t$-test).

Abbreviations: GPT, glutamic-pyruvic transaminase; GOT, glutamic-oxaloacetic transaminase.

$(P \leq 0.05)$, respectively, whereas the aminotransferases such as GPT and GOT were $65 \%-211 \%$ and $28 \%-119 \%$, respectively. Thus, the results reflected that the cold-stress treatment caused increasing trend of activation of all these enzymes in the silk gland over the increasing periods of exposure to cold stress.

In the fat body of the insect larvae, the impact of cold stress was found to be different (Table 6). The significant elevations in the activities of the hydrolases were recorded due to cold stress; the values being maximum for alkaline phosphatase (269\%), followed by acid phosphatase (142\%) after the 7th day of the exposure. However, only a small increase $(8.6 \%)$ in the activity of GPT and an insignificant decrease $(8 \%)$ in the activity of GOT were observed.

\section{Discussion}

Many researchers have reported that the insect brain which receives the alteration signs of the factors, such as photoperiod and thermoperiod, causes the changes of nerve and endocrine systems affecting physiological and biochemical variations in the body. ${ }^{7}$ In the present study it is seen that the silkworm $P$. ricini exhibits marked changes in its metabolic activity in response to low temperature acclimatization. The mortality of $P$. ricini at low temperature exposure is time-dependent. The larvae lose their capacity to spin normal cocoons when reverted back to normal temperature. The probable reason behind this 
Table 6 Effect of exposure to low temperature $\left(10^{\circ} \mathrm{C}\right)$ on some key enzymes in the fat body of 5 th instar larvae of Philosamia ricini exposed for different days

\begin{tabular}{lllll}
\hline Enzymes & $\begin{array}{l}\text { Control } \\
\text { (units } \mathbf{~ m g}^{-1} \\
\text { protein) }\end{array}$ & \multicolumn{3}{l}{ Experimental (units $\mathbf{~ m g}^{-1}$ protein) } \\
\cline { 3 - 5 } & $19.6 \pm 0.28$ & $28.2 \pm 0.18$ & $35.5 \pm 0.20^{c}$ & $47.3 \pm 0.21$ \\
\hline Acid & & $(+43.8)$ & $(+8 I .1)$ & $(+141.7)$ \\
phosphatase $^{\mathrm{a}}$ & & $12.4 \pm 0.06$ & $18.5 \pm 0.08$ & $24.0 \pm 0.04^{\mathrm{c}}$ \\
Alkaline & $6.5 \pm 0.03$ & $(+90.7)$ & $(+184.6)$ & $(+268.5)$ \\
phosphatase & & $16.4 \pm 1.22$ & $16.8 \pm 1.30^{\mathrm{c}}$ & $17.4 \pm 1.32$ \\
GPT & $15.9 \pm 1.32$ & $(+3.1)$ & $(+5.6)$ & $(+8.6)$ \\
& & $45.2 \pm 1.20$ & $44.2 \pm 1.18^{\mathrm{c}}$ & $42.6 \pm 1.22^{\mathrm{c}}$ \\
GOT & $46.3 \pm 2.14$ & $(2.4)$ & $(4.5)$ & $(7.9)$ \\
\hline
\end{tabular}

Notes: $P$. ricini 5 th instar larvae (50 in each experimental set) was acclimated for 7 days at $10^{\circ} \mathrm{C} \pm 1{ }^{\circ} \mathrm{C}$ for the experimental set, whereas the control group insects were reared at $25^{\circ} \mathrm{C} \pm 3^{\circ} \mathrm{C}$. I unit of phosphatase has been defined as the $\mathrm{I} \mathrm{mg} \mathrm{Pi}$ per $100 \mathrm{~mL} / \mathrm{h}$ and I unit of the activity of transaminases as I mM pyruvate per $\mathrm{mL}$ per 30 minutes for GPT and per 60 minutes for GOT. The specific activity has been expressed as units/mg protein. The results represent the average values of three independent experiments. The values in parentheses indicate percent increase $(+)$ or decrease $(-)$ over control. ${ }^{a, b}$ The values are to be multiplied by a factor of $10 .{ }^{4}$ 'Significantly different at $P \leq 0.05$ (Students' $t$-test).

Abbreviations: GPT, glutamic-pyruvic transaminase; GOT, glutamic-oxaloacetic transaminase.

altered behavior due to the severe cold stress could be that the corpora allata gland of the insect is stimulated to increase the hemolymph juvenile hormone titer, which consequently inhibits the activity of the prothoracic gland and arrests larvalpupal ecdysis..$^{22,23}$

It is seen that the exposure to low temperature stimulates the accumulation of low molecular weight cryoprotectants and synthesis of some antifreeze proteins. ${ }^{24,25}$ In our study, the observed increase in the protein content in the hemolymph tissue of cold-stressed larvae reflects on the reduced amount of food intake at low temperature. This also confirms that proteins are not a source of energy in colder environments, but are involved in lowering the super cooling and freezing points and thus protect the larvae from injury caused by ice crystals. ${ }^{7,26}$ Perhaps trehalose, a major carbohydrate, alone needs the energy requirement during this period, since a decrease is observed in contents after low temperature acclimatization. ${ }^{27-29}$

Although glycerol is the most common cryoprotectant in overwintering insects, other commonly reported compounds are trehalose, glucose, fructose, sorbitol, and mannitol. These compounds are believed to protect organisms during both freezing and thawing and prolonged exposures to low non freezing temperatures in various ways. ${ }^{7}$ The advantage of polyols as cryoprotectants is that they may dissolve in water, penetrate freely through membranes in or out, as well as not interfering with the metabolic procedures. Besides, they can stabilize natural state of protein and prevent denaturation of proteins at sub optimal temperatures or freezing. ${ }^{7,30}$

In our study, the accumulation of glycerol confirms that this lepidopteron insect survives severe cold exposure for one week mainly due to its cryoprotective nature. It seems that cryoprotective effect of glycerol is based on the colligative properties of the substances. Glycerol has the ability to lower the concentration of potentially harmful solutes by colligative means. Thus, it protects the insect from damage due to freezing. ${ }^{8,9,30,31}$

Decrease in the free amino acid content in fat body of stressed $P$. ricini larvae may indicate the possibility of active feeding of amino acid in Kreb's cycle and glycolytic pathway to meet the emergent energy needs as well as their utilization in the production of some new proteins synthesized to cope with the low temperature stress. ${ }^{7,12}$

Hydrolase is a group of enzymes that catalyzes the hydrolysis of a chemical bond during a metabolic process and is mainly involved in lysosomal activities. The significant increase in the levels of key hydrolases such as acid and alkaline phosphatases in silk gland and fat body may be due to the rupturing of various cellular and lysosomal membranes that contain the hydrolytic enzymes, resulting in an increase in their activities as reported by other workers. ${ }^{11,32,33}$ These results also indicate that cold stress targets primarily the activities of silk glands and fat body in the larvae of silkworm.

Transaminases are the group of enzymes involved in the reversible transfer of an amino $\left(\mathrm{NH}_{2}\right)$ group from an $\alpha$-amino acid to an $\alpha$-ketoacid, especially $\alpha$-ketoglutaric acid. The observed decrease in activity of the enzymes., GPT and GOT in hemolymph and fat body is suggestive of their subdued functions at low temperature. ${ }^{12}$

In conclusion, it was observed that trehalose had a protective role in response to cold stress in P. ricini larvae; therefore, the increased concentration of trehalose should have been expected. In another study with $C$. riparius exposed to anoxia it has been reported that the decrease of total protein content is indicative of its degradation into amino acids as they contribute to energy supply in the insect. ${ }^{12}$ In the present investigation, when the P. ricini larvae were exposed to cold stress, similar results were obtained. In consonance to the above findings, the enhancement in the activities of transaminases as observed in the silk gland and the fat body tissues of the cold-stressed P. ricini larvae indicated that both transaminases, GOT and GPT, might lead to the supply of the precursors for the Krebs cycle towards generation of the energy, as it is known that many amino acids and metabolites 
can lead to pyruvate production. Similar observations have been reported in $C$. riparius larvae exposed to anoxia. ${ }^{12}$ The drastic elevation in the activities of hydrolases in the silk gland and fat body of the $P$. ricini larvae exposure due to cold stress reflected probable breakdown of the tissues concerned.

\section{Acknowledgment}

The authors (AS and RKS) are grateful to the University Grants Commission (UGC) - New Delhi, India for providing financial support in the form of research scholarships.

\section{Disclosure}

The authors report no conflicts of interest in this work.

\section{References}

1. Asahina E. Frost resistance in insects. Adv Insect Physiol. 1969; $6: 1-29$.

2. Baust JC. Mechanisms of cryoprotection in freezing tolerant animal systems. Cryobiol. 1973;10:197-205.

3. Hayakawa Y, Chino H. Temperature-dependent interconversion between glycogen and trehalose in diapausing pupae of Philosamia Cynthia ricini and pryeri. Insect Biochem. 1981;11:43-47.

4. Redway KF, Lapage SP. Effect of carbohydrate and related compounds on long-term preservation of freeze-dried bacteria. Cryobiology. 1974;11:73.

5. Sinclair BJ, Vernon P, Klok CJ, Chown SL. Insects at low temperatures: an ecological perspective. Trends Eco Evol. 2003;18(5):257-262.

6. Storey KB. Biochemical adaptation for cold hardiness in insects. Phil Trans R Soc Lond B. 1990;326:635-654.

7. Zhao Z. Progress in the research on mechanism of insects cold-hardiness. Entomol Sinica. 1997;4(3):265-276.

8. Churchill TA, Storey KB. Metabolic correlates to glycerol biosynthesis in a freeze-avoiding insects, Epiblema scudderiana. J Comp Physiol. 1989;159(4):461-472.

9. Frankos VH, Platt AP. Glycerol accumulation and water content in larvae of Limenitis archippus: their importance to winter survival. J Insect Physiol. 1976;22:623-628.

10. Dash R, Mukherjee S, Kundu SC. Isolation, purification and characterization of silk protein sericin from cocoon peduncles of tropical tasar silkworm, Antheraea mylitta. Int J Biol Macromol. 2006;38:255-258.

11. Pant R, Morris ID. Variation in glycogen, total free sugars, protein, alkaline and acid phosphatases, citrate and inorganic phosphorus level in fat body of P. ricini (Eri-silkworm) during development. J Biochem. 1972;71(1):1-8.

12. Forcella M, Berra E, Giacchini R, Parenti P. Antioxidant defenses preserve membrane transport activity in Chironomus riparius larvae exposed to anoxia. Archv Insect Biochem Physiol. 2007;65: 181-194.

13. Ringer $\mathrm{S}$. Concerning the influence exerted by each of the constituents of the blood on the contraction of the ventricle. J Physiol Cambridge. 1980-1982;3:380-393.

Open Access Insect Physiology

\section{Publish your work in this journal}

Open Access Insect Physiology is an international, peer-reviewed, open access journal publishing original research, reports, reviews and commentaries on all areas of insect physiology. The manuscript management system is completely online and includes a very quick and fair peer-review system, which is all easy to use.
14. Ringer S. Concerning the influence exerted by each of the constituents of the blood on the contraction of the ventricle. J Physiol Cambridge. 1983-1984;4:29-42, 222-225.

15. Lowry OH, Rosebrough NJ, Farr AL, Randall RJ. Protein measurement with the Folin-Phenol Reagent. J Biol Chem. 1951;193:266-275.

16. Trevelyan WE, Harrison JS. Studies on yeast metabolism. I. Fractionation and microdetermination of cell carbohydrates. Biochem J. 1952;50:298-303.

17. Wyatt GR, Kalf GF. Organic components of insect haemolymph. Proc 10 th Int Congr Ent. 1958;2:333.

18. Rosen H. A modified ninhydrin colorimetric analysis for amino acids. Archs Biochem Biophys. 1957;67:10-15.

19. Korn ED. Clearing factor, A heparin-activated lipoprotein lipase: I. Isolation and characterization of the enzyme from normal rat heart. J Biol Chem.1955;215:1-14.

20. Fiske $\mathrm{CH}$, Subbarow Y. The colorimetric determination of phosphorous. J Biol Chem. 1925;66:375-379.

21. Reitman S, Frankel S. A colorimetric method for the determination of serum glutamic oxaloacetic and glutamic pyruvic transaminases. $\mathrm{Am}$ J Clin Pathol. 1957;28:56.

22. Pant R, Agarwal HC. Some quantitative changes observed in P. ricini pupal haemolymph during metamorphosis. Biochem J. 1965;96:824.

23. Xu L, Neven LG, Duman JG. Hormonal control of haemolymph lipoprotein ice-nucleators in overwintering freeze-susceptible larvae of the stag beetle Ceruchus picueus: adipokinetic hormone and juvenile hormone. J Comp Physiol. 1990;160:51-59.

24. Duman JD, Wu DW, Xu L, Tursman D, Olsen TM. Adaptations of insects to subzero temperatures. Quart Rev Biol. 1991;66:387-410.

25. Knight CA, Duman JG. Inhibition of recrystallization of ice by insect thermal hysteresis proteins: a possible cryoprotective role. Cryobiol. 1986;23:256-262

26. Omana J, Gopinathan KP. Heat shock response in mulberry silkworm races with different thermotolerances. J Biosci. 1995;20(4):499-513.

27. Lee RE, Strong-gunderson JM, Lee MR, Davidson EC. Ice-nucleating active bacteria decrease the cold-hardiness of stored grain insect. Entomol Soc Am. 1992;85:371-374.

28. Lee RE, Mcgrath JJ, Morason RT, Taddeo RM. Survival of intracellular freezing, lipid coalescence and osmotic fragility in fat body cells of the freeze tolerant gall fly Eurosta solidaginis. J Insect Physiol. 1993;39:445-450.

29. Mansingh A, Smallman BN. Variation in polyhydric alcohol in relation to diapauses and cold-hardiness of the larvae of Isia Isabella. J Insect Physiol. 1972;16:979-990.

30. Lee RE, Denlinger DL, eds. Principles of insect low temperature tolerance. In: Insects at Low Temperature. New York: Chapman and Hall; 1991:17-45.

31. Zachariassen KE. The mechanism of the cryoprotective effect of glycerol in beetles tolerant to freezing. J Insect Physiol. 1979;25:29-32.

32. Csikos G, Sass M. Changes of acid phosphatase content and activity in the fat body and the hemolymph of the flesh fly Neobellieria (Sarcophaga) bullata during metamorphosis. Arch Insect Biochem Physiol. 1998;34(3):369-390.

33. Pinoni SA, Lopez MAA. Alkaline phosphatase activity sensitive to environmental salinity and dopamine in muscle of the euryhaline crab Cyrtograpsus angulatus. J Exp Marine Biol Ecol. 2004; 307(1):35-46.

Visit http://www.dovepress.com/testimonials.php to read real quotes from published authors. 